\title{
THE ROLE OF ICT TO RAISE STUDENTS' ACHIEVEMENT IN ITALIAN TECHNICAL AND PROFESSIONAL SCHOOLS
}

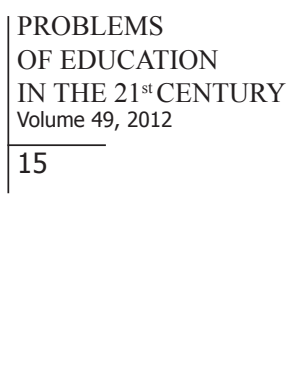

\author{
Michela Freddano \\ University of Genova, Genova, Italy \\ E-mail: michela.freddano@unige.it \\ Paolo Diana \\ University of Salerno, Salerno, Italy \\ E-mail: diana@unisa.it
}

\begin{abstract}
The research examines the role of using ICT to raise students' achievement in Italian technical and professional schools. The hypothesis developed in this research is that students who obtain better learning results are those students who use ICT more than those students who are low performers. Data from the Programme for International Student Assessment (PISA) 2009 by OECD (Organisation for Economic Co-operation and Development) have been analyzed. The relationship between using ICT at school and students' digital skills and attitudes has been analyzed by comparing the lowest performers and strong performers in reading literacy in Italian technical and professional schools. Results show that in Italian technical and professional schools, strong performers in reading literacy in PISA 2009 are more capable to do tasks at computer than low performers; however reading online and using ICT have greater positive effects towards achievement among low performers.
\end{abstract}

Key words: ICT, PISA, professional school, reading literacy, technical school.

\section{Introduction}

Digital skills are essential for lifelong learning and active engagement in social life (Van Dijk, 2005; IEA, 2006). Young people are early adopters and the most users of ICT in different areas of daily life; on the other hand they are the first to meet digital inequalities in using ICT for participating in society.

By time problems on digital divide move from the question of having or not a desktop computer to the second-level digital divide, that regards how ICT tools are used by connected people, passing from a technological question to cultural problems (Jenkins et al., 2010) about having or not a fast Internet connection, using information from Internet, having formal and informal online relationships (Hargittai, 2002, 2010). Recent studies (Gui \& Accorsi, 2006; Gui \& Micheli, 2011) underline the effects of variables such as age, gender, education level, economic social and cultural background, immigrant status (native or immigrant) and place of living, not only on Internet availability but also on digital media usability.

The European Commission takes into account the use of new information and communication technologies (ICT) in education such as a strategy for the effectiveness of European educational systems and for the competitiveness of the European economy (European Commission, 2000, 2008; Eurydice, 2011). European countries where there is a higher percentage of ICT users with high digital skills, better perform in PISA. Figure 1 shows the 
PROBLEMS

OF EDUCATION

IN THE $21^{\text {st }}$ CENTURY

Volume 49, 2012

16

match between the percentage of individuals aged 16 to 74 with a high level of basic computer skills $^{1}$ and the reading literacy average in PISA 2009 for the European countries, distributing them above and below the OECD average in reading literacy (493) and above and below the European average of people with high level of basic computer skills (27\%). The color of plots distinguishes between the quartiles of the distribution of individuals with a high level of basic Internet skills ${ }^{2}$.

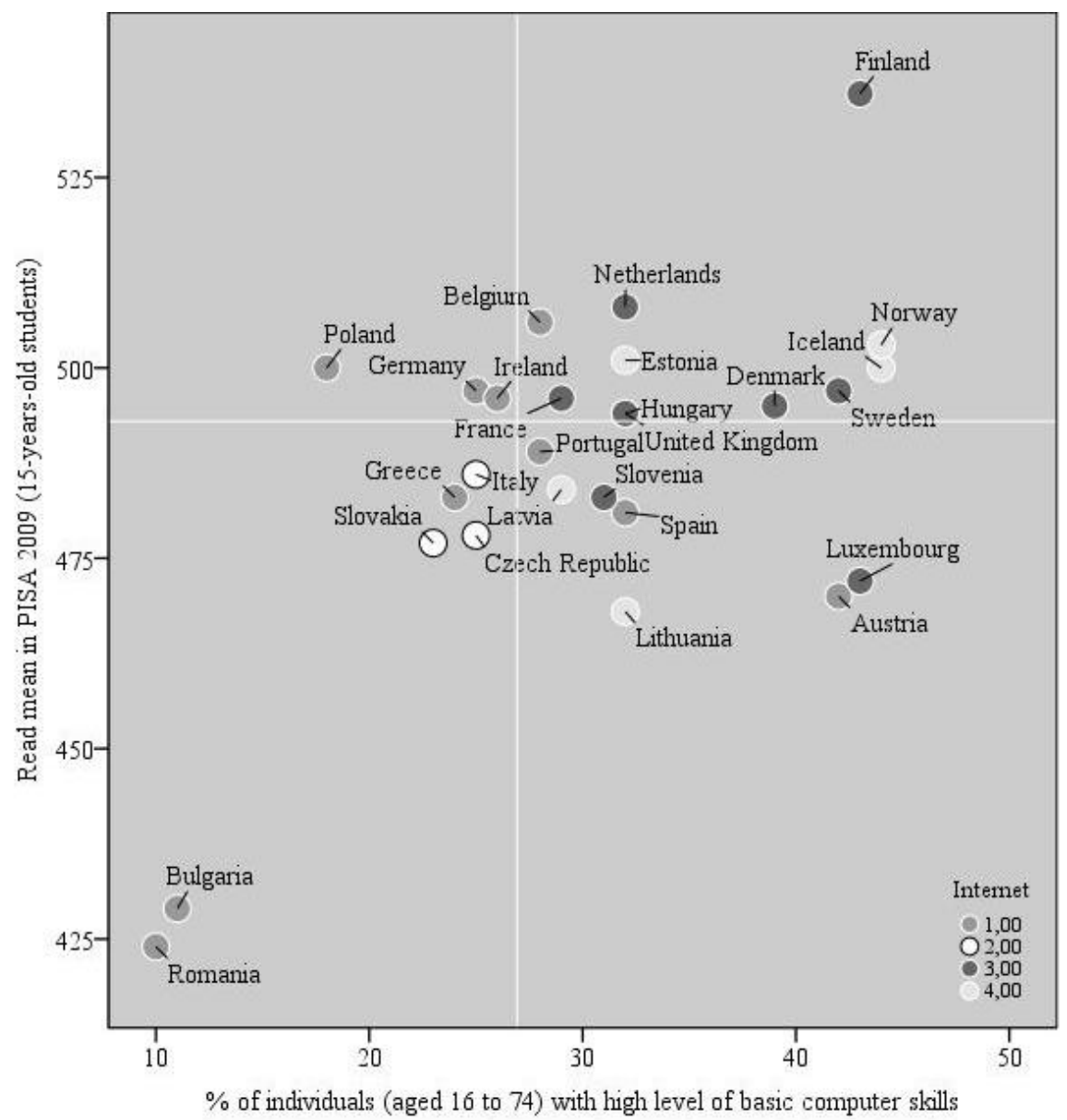

Figure 1: Availability of digital technologies and student achievement among European Union countries.

Particularly, North Europe countries are characterized by high percentages of individuals with high computer skills and by the best results in PISA 2009. Bulgaria and Romania have critical conditions. Italy ${ }^{3}$, as well as Greece, Slovakia and Czech Republic are below the OECD average in reading literacy and below the European percentage of individuals with high computer skills.

In that framework, school is invested by an important role in young people's socialization towards using ICT and international surveys, such as the International Programme for Student Assessment (PISA) by OECD and the Second Information Technology in Education (SITES) by International Association for the Evaluation of Educational Achievement (IEA) ${ }^{4}$ examine the effectiveness of using ICT at school (Melchiori, 2012).

In Italy, investments on ICT are increased at different levels of school system to develop the implementation of new technologies in pedagogical and organizational processes at school 
and to improve digital skills among Italian teachers (Pandolfini, 2010). Particularly, technical and professional schools are defined "schools of innovation" (MIUR, 2007) because they promote the development of technologies among young people who, on average, have difficulty or don't like traditional studies but that can be involved in practical activities, such as laboratories and school-work, where ICT are considered central to empower cognitive and social skills.

Starting from these assumptions, the purpose of this research is to examine the role of using ICT to raise students' achievement in Italian technical and professional schools.

The research object is the use of ICT on reading literacy among Italian population of 15year-old students from technical and professional schools, comparing lowest performers and strong performers in reading literacy about using ICT at school and having digital skills and attitudes towards the use of computer.

The research is focused on PISA 2009 data, available from the OECD website www.pisa. oecd.org. PISA is an internationally standardized assessment to measure how well students, at age 15, are prepared to meet the challenges they may encounter in future life. PISA 2009 is the fourth cycle of a data strategy defined in 1997 by participating countries, OECD members and partner countries/economies ${ }^{5}$. PISA focuses on the assessment of literacy in reading, mathematics and science, combining it with information on students' family background, their approach to learning, their learning environment and their familiarity with computers (OECD, 2009a). The process of analyzing data is described in the technical report (OECD, 2012) and in the data analysis manual (OECD, 2009b). Results from PISA 2009 are organized in six OECD publications and, in particular, the Volume VI (OECD, 2011) explores students' ICT use to learn.

\section{Problem of Research}

PISA 2009 results show the existence of negative relationships between the increasing of using ICT at school and student achievement (OECD, 2011), suggesting in educational policymakers and experts reflection on methods by which ICT effectively can improve school systems and educational processes,

The problem of this research regards how ICT tools are used in Italian technical and professional schools and if there are differences in using ICT between students who are good performers and students who proficient bad, starting from the evidences that in Italy the cultural capital and the social capital from family background affect student school choice; inequalities among young people and their success in term of different life's opportunities are determined by the type of the attended school (high school, technical school, professional school or vocational school) (Schizzerotto, 2002); students from technical and professional schools are more disadvantaged and perform lower than students from high schools (OECD, 2010; INVALSI, 2011, 2012); in technical and professional schools ICT are used greater than in high schools (MIUR, 2007).

\section{Methodology of Research}

\section{General Background of Research}

Data from PISA 2009 have been analysed by using a quantitative approach of research and using statistical procedures of analysis.

Reading literacy is the main domain of PISA 2009; the PISA assessment framework (OECD, 2009a) defines "reading literacy" such as an individual's capacity to understand, use, reflect on and engage with written texts, in order to achieve one's goals, to develop one's knowledge and potential, and to participate in society (OECD, 2009a:14). Proficiency has been 
PROBLEMS

OF EDUCATION

IN THE $21^{\text {st }}$ CENTURY

Volume 49, 2012

developed by OECD for all the assessment domains using Item Response Theory and realizing scales divided according to levels of difficulty and performance and a description of the skills associated with that proficiency level can be obtained; each successive level is associated with tasks of increased difficulty (OECD, 2009a). In PISA 2009, the OECD average is 493, with a standard deviation of 93: this establishes the benchmark against which each country's reading performance in PISA 2009 is compared ${ }^{6}$ (OECD, 2010:55).

In PISA 2009, seven levels of reading literacy scale have been developed. OECD categorized student performances on the basis of students' level proficiency: top performers are those students proficient at level 5 or 6 of the assessment (more than 626 points of reading literacy); strong performers at level 4 (student score in reading literacy between or equal to 553 and 625); moderate performers at level 2 or 3 (student score in reading literacy between or equal to 407 and 624) and lowest performers below level 2 (student score in reading literacy minor than 407: level 1a, level 1b and below level 1b) (OECD, 2010:32) ${ }^{7}$. OECD describes for each level of the reading scale the student abilities in reading literacy. A computer familiarity questionnaire for students was offered as international option, that Italy incorporated. It focuses on using ICT, taking into account where ICT is mostly used, students' ability to carry out computer tasks and their attitudes towards using ICT (OECD, 2009a:16).

\section{Sample of Research}

Starting from the fact that at the highest levels of reading proficiency (levels 5 and 6) there are few students and, particularly, in Italy, $2.5 \%$ of students from technical schools and $0.6 \%$ from professional schools, the level 4 of the reading scale has been assumed as indicator of high reading proficiency and the levels under the second level (defined baseline by OECD) as indicator of low reading proficiency. Two subgroups of students from the 17,607 students of 15 -year-old ${ }^{8}$ nested in 322 technical schools and 228 professional schools in Italy sampled in PISA 2009 have been selected: the groups of lowest performers $(20.2 \%$ of students from technical schools and $46 \%$ from professional schools) and the groups strong performers $(15.1 \%$ of students from technical schools and 5.2\% from professional schools).

\section{Instrument and Procedures}

Data analysis shows the composition of strong performers and the lowest performers nested in the Italian technical and professional schools in terms of gender (males/females), immigration background (native students/immigrant student) and family background. Successively, for each group, the study examines the availability of equipment and the ICT use at school, the use of computer for educational activities in school, the students' self-confidence to do tasks at computer and their attitude towards using ICT.

The index of economic, social and cultural status (ESCS) is derived by OECD from a principal component analysis of the following standardized variables (with OECD mean of zero and a standard deviation of one): highest occupational status of parents, highest educational level of parents in years of education according to ISCED and home possessions, as well as books in the home.

Students' information on ICT is derived from the ICT familiarity questionnaire. The items of using ICT at school and of self-confidence to do tasks at computer are estimated by students' responses from Likert scales. The index of online reading is computed by OECD by using the frequency with which students are involved in reading emails, chatting online, reading online news, using and online dictionary or encyclopedia, searching online information to learn about a particular topic, taking part in online group discussions or forums, and searching practical 
information online (OECD, 2011:225). The index of attitude towards computer is estimated by OECD by using students' reports on the extent to which they agree with the importance to work with a computer, the enjoyment to work with computer, the interest in using computer and the time spent working with computer (OECD, 2011:227).

\section{Data Analysis}

Multivariate analysis has been done on PISA 2009 database of students by SPSS (Statistical Package for Social Science) software. PISA data needs to be weighted to avoid biases; more information on analyzing data are described in the technical report (OECD, 2012) and in the data analysis manual (OECD, 2009b).

The percentages of students from technical and professional schools at level 4 and below the level 2 of the reading scale have been computed and the abilities defined by OECD have been described for the sub-groups of lowest and strong performers from Italian technical and professional schools.

Successively the variables of gender, immigrant status and social, economic and cultural background have been examined in each sub-group by computing the percentages of males, females and immigrants and the mean of the index of ESCS. After that, using ICT and student digital abilities have been examined in each sub-group by computing the percentages of students who use or not ICT at school and of students who are able or not to do some tasks at computer by using the information derived from students' responses to the ICT questionnaire.

\section{Results of Research}

\section{The Performances in Reading Literacy of the Lowest and Strong Performers}

The $15.1 \%$ of students from technical schools and the $5.2 \%$ from professional schools are strong performers: those students proficient at level 4 on the reading scale who have scores higher than 553 points but lower than or equal to 626 points.

The OECD explains that students at this level understand long or complex texts whose content or form may be unfamiliar. The reading tasks are difficult, for example locating embedded information, construing meaning from nuances of language and critically evaluating a text. The required tasks are: retrieving information; locating and organizing pieces of embedded information; interpreting the meaning of a part of the text by taking into account the text as a whole; understanding and applying categories in an unfamiliar context and reflecting using formal or public knowledge to formulate hypothesis or critically evaluate a text.

On the other hand the $20.2 \%$ of students from technical schools and the $46 \%$ from professional schools are lowest performers: those students under the baseline level on the reading scale who have scores lower or equal to 407 points. PISA 2009 selects two levels under the baseline level: the level $1 \mathrm{a}$ and the level $1 \mathrm{~b}$.

Students proficient at level 1a of the reading scale have scores higher than 335 but lower than or equal to 407 points. The $16.1 \%$ of students from technical schools and the $29 \%$ from professional schools are at level 1a. That means they are capable of locating one or more independent pieces of explicitly stated information; of recognizing the main theme or author's purpose in a text about a familiar topic; making a simple connection between information in the text and common everyday knowledge. Typically the required information in the text is prominent and there is little, if any, competing information. Students are explicitly directed to consider relevant factors in the tasks and in the texts.

Students proficient at level $1 \mathrm{~b}$ of the reading scale have scores higher than $262 \mathrm{but}$ lower than or equal to 335 points. The $3.5 \%$ of students from technical schools and the $13.6 \%$ from 
PROBLEMS

OF EDUCATION

IN THE $21^{\text {st }}$ CENTURY

Volume 49, 2012

20

professional schools are at level $1 \mathrm{~b}$. They can find explicitly stated information in short, simple texts with a familiar style and content. Tasks at this level require the students to locate a single piece of explicitly stated information in a prominent position in a short, syntactically simple text with a familiar context and text type, such as a narrative or a simple list. The text typically provides support to the readers, such as repetition of information, pictures or familiar symbols; there is minimal competing information. In tasks requiring interpretation students may need to make simple connections between adjacent pieces of information.

Finally students proficient below level $1 \mathrm{~b}$ are out of the reading scale and have scores lower than or equal 262 points. This doesn't mean that they are necessarily completely illiterate, but that there is insufficient information on which to base a description of their reading proficiency. In the Italian school system only the $0.6 \%$ of students from technical schools, but the $3.4 \%$ of students from professional schools are under the level $1 \mathrm{~b}$, underlining situations of disadvantage at risk of exclusion.

\section{The Social, Economic and Cultural Background of the Lowest and Strong Performers}

In technical schools, there is a greater incidence among females (36.7\%) than among males $(28.8 \%)$ at level 4 of the reading scale (strong performers); on the other hand $11.4 \%$ of females and $25 \%$ of males are low the baseline level, with a greater incidence at level $1 \mathrm{a}$. The incidence of lowest performers among immigrant students (28.6\%) is higher than among native students (19.5\%); while there is a similar presence of strong performers among natives (31.9\%) and immigrants $(29.1 \%)$. More precisely the $20.7 \%$ of immigrants is at level $1 \mathrm{a}$, the $6.8 \%$ at level $1 \mathrm{~b}$ and the $1.1 \%$ below the level $1 \mathrm{~b}$.

In technical schools, females are the $48 \%$ in the group of strong performers and the $19.6 \%$ in that of students below the baseline level, so that there is a greater presence of males among lowest performers. The $7.2 \%$ of lowest performers and the $1.9 \%$ of strong performers are immigrants. The social, economic and cultural conditions are different between the two groups and confirm the trends of the population of Italian students: the higher social, economic and cultural status, the highest score in reading literacy (OECD, 2010). The social, economic and cultural index, computed by OECD, is on average below the OECD average (equal to 0 ) in both lowest and strong performers and it is lower among lowest performers (-0.457) than among strong performers $(-0.111)$.

In professional schools the situation is more critic than in technical schools. There is a lesser incidence of strong performers among males $(11.9 \%)$ and females $(24 \%)$ and more than an half of males $(56.6 \%)$ and the $32.5 \%$ of females are below the baseline level, in particular at levels $1 \mathrm{a}$ ( $23.2 \%$ of females and $33.5 \%$ of males) and $1 \mathrm{~b}$ ( $8 \%$ of females and $18 \%$ of males). Moreover there is a short percentage of students below the minimum level (1.3\% of females and $5 \%$ of males). More than an half of immigrant students (60.7\%) are lowest performers; also the $44.3 \%$ of natives have the lowest proficiency in reading, while only the $18.1 \%$ of natives and the $8.6 \%$ of immigrants are strong performers so that the difficulties of natives and, overall, of immigrants are greater in professional schools than in technical schools. The $28.6 \%$ of natives and the $34.4 \%$ of immigrants are at level $1 \mathrm{a}$; the $12.9 \%$ of natives and the $18.7 \%$ of immigrants are at level $1 \mathrm{~b}$ and $2.8 \%$ of natives and $7.6 \%$ of immigrants are unclassified in reading scale because they are under the minimum level.

In the groups examined here, females are the $72.3 \%$ of strong performers and the $31.2 \%$ of the lowest performers; the $10.5 \%$ of lowest performers and the $2.3 \%$ of strong performers are immigrants. The social, economic and cultural background is under the OECD average and lower among the lowest performers $(-0.710)$ than among strong performers $(-0.233)$. 


\section{Differences between the Lowest and Strong Performers in Using ICT at School}

All the strong performers in both technical and professional schools (respectively $99.2 \%$ and $99.4 \%$ ) use a computer; while not all the lowest performers have ever used a computer, especially in professional schools $(8.7 \%)$ than in technical ones $(5.6 \%)$.

The availability of hardware at school is diffused both in technical and professional schools.

In technical schools using desktop computer is diffused, especially among strong performers $(82.8 \%)$ than lowest performers $(71.3 \%)$ who affirm to use more portable laptops or notebooks $(9.3 \%)$ than students with higher performances (only the 1.7\%). Moreover, the $44 \%$ of the lowest performers and the $55.4 \%$ of strong performers use an Internet connection at school. In professional schools similar percentages of students (more or less $62 \%$ ) within the two groups use a desktop computer; while portable laptop or notebook is more diffused among the lowest performers $(11.1 \%)$ than among strong performers $(2.9 \%)$. Internet connection at school is diffused in more or less an half of students from both the groups (48-50\%). Using printer is more diffused among strong performers $(55.4 \%$ from technical schools and $51.2 \%$ from professional schools) than lowest performers (36.9\% from technical schools and $43.4 \%$ from professional schools).

Most of the students examined here don't spend time using computer during classroom lessons; in particular, using computer has a greater incidence in test language lessons and in science lessons among lowest performers. Figure 1 shows that many students use computer to browse for school and to do practice or to drill with a higher incidence of strong performers from technical schools and of the lowest performers from professional schools. In general, the lowest performers use computer greater than strong performers to do group work and homework, to have simulations, to download from website, to post on website and to communicate by chats and e-mails.

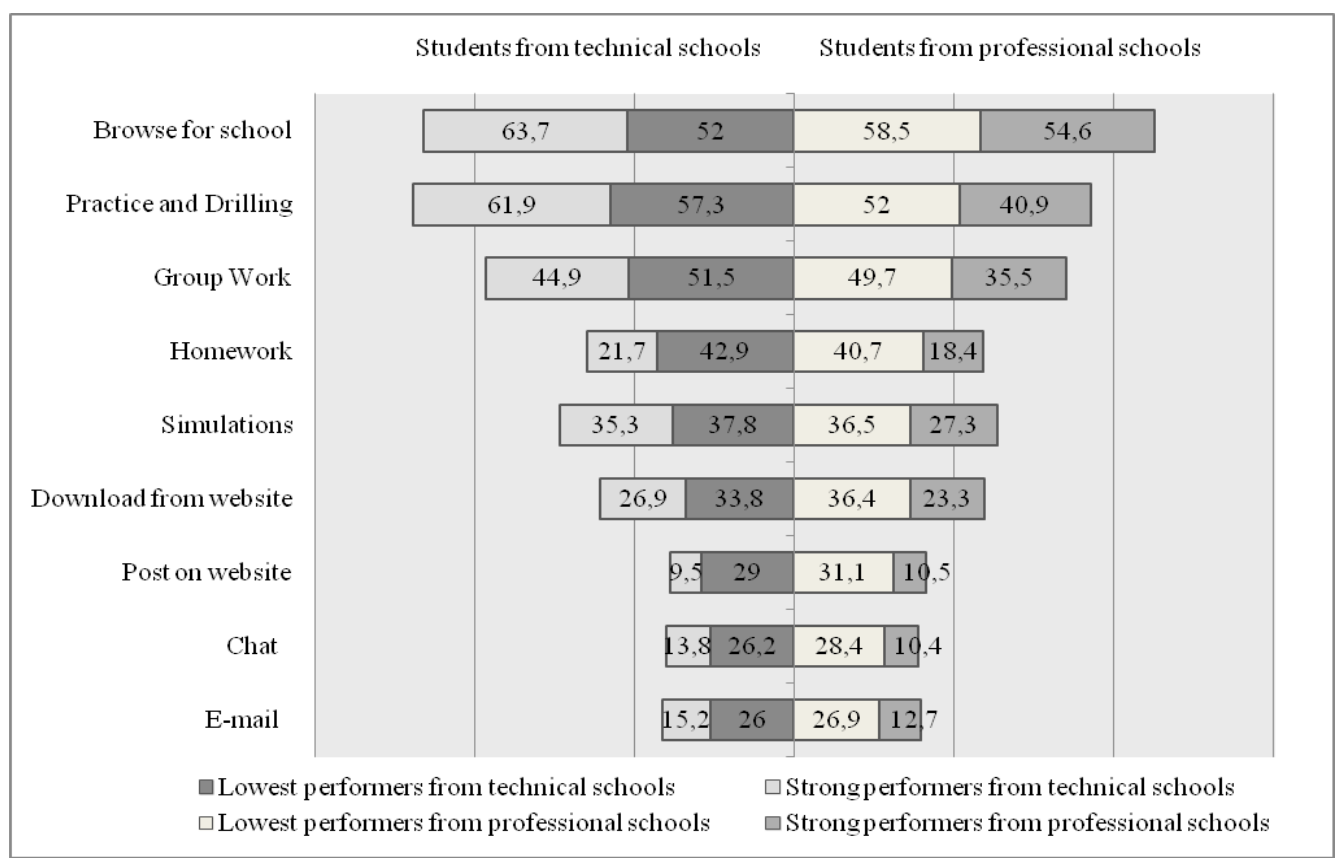

\section{Figure 1: Percentage of strong and lowest performers from technical and professional schools who use a computer at school for some activities.}


PROBLEMS

OF EDUCATION

IN THE $21^{\text {st }}$ CENTURY

Volume 49,2012
Students'Ability to Do Tasks on a Computer and Their Attitude towards ICT Use

In both technical and professional schools strong performers' groups are more selfconfident in ICT high-level tasks than the lowest performer to edit digital photographs or other graphic images; to use a spreadsheet to plot a graph and to create a presentation (e.g. by using Microsoft Power Point) or a multimedia presentation with sounds, pictures and videos. On the other hand the lowest performers are more able to create a database than strong performers. Table 1 shows the percentage of strong and lowest performers in both technical and professional schools that are able to do these tasks very well by themselves or with the help from someone.

Table 1. Percentage of lowest and strong performers from Italian technical and professional schools that are able to do tasks on computer.

\begin{tabular}{|c|c|c|c|}
\hline & $\begin{array}{c}\text { Proficiency sub- } \\
\text { group }\end{array}$ & $\begin{array}{c}\text { Technical } \\
\text { schools }\end{array}$ & $\begin{array}{c}\text { Professionals } \\
\text { schools }\end{array}$ \\
\hline \multirow{2}{*}{ Edit digital photographs or other graphic images } & Lowest & 84.1 & 79.9 \\
\cline { 2 - 4 } & Strong & 86.9 & 82.5 \\
\hline \multirow{2}{*}{ Create a database (e.g. using Microsoft Access) } & Lowest & 59.4 & 60.4 \\
\cline { 2 - 4 } & Strong & 46.4 & 38.8 \\
\hline \multirow{2}{*}{\begin{tabular}{c} 
Use a spreadsheet to plot a graph \\
\cline { 2 - 4 }
\end{tabular}} & Lowest & 69.4 & 66.9 \\
\hline $\begin{array}{c}\text { Create a presentation } \\
\text { (e.g. using Microsoft PowerPoint) }\end{array}$ & Strong & 87.8 & 76.0 \\
\cline { 2 - 4 } & Lowest & 79.1 & 76.5 \\
\hline \multirow{2}{*}{$\begin{array}{c}\text { Create a multi-media presentation } \\
\text { with sounds, pictures, videos }\end{array}$} & Strong & 95.1 & 91.0 \\
\cline { 2 - 4 } & Lowest & 82.5 & 80.1 \\
\hline
\end{tabular}

Figure 2 shows the reading literacy scores for the first and last quartiles of the distribution of the indexes of online reading and of attitude towards computer per lowest and strong performers in technical and professional schools. The analysis shows the positive increase of the reading literacy scores from the first quartile to the last quartile of the distribution of the examined indexes among the lowest performers; while there are not significant differences among strong performers. 


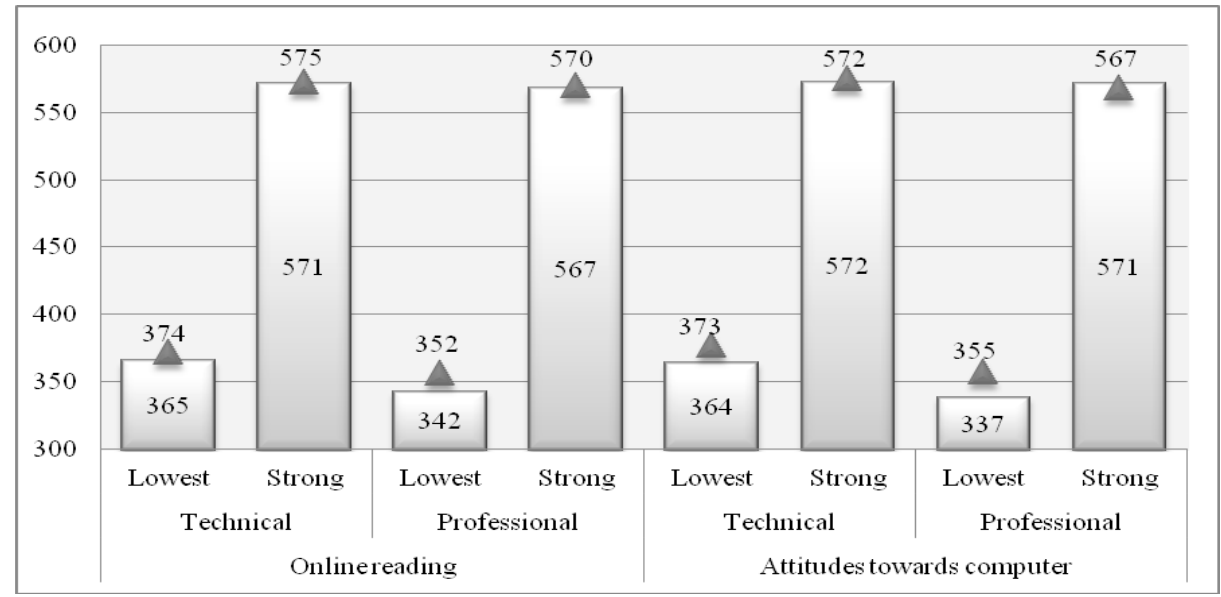

Figure 2: Score in reading literacy of lowest and strong performers from technical and professional schools for the first and last quartiles of the distribution of the indexes of online reading and attitudes towards computer.

\section{Discussion}

The analysis underlines that using ICT is diffused in Italian technical and professional schools but that there are differences in the ICT use among students that are strong performers and students that are lowest performers in PISA 2009, in terms of social, cultural and economic status and of abilities and motivation in using ICT.

The analysis confirms that there is a positive relationship between the social, cultural and economic status of students and their achievement., Differences emerge between the groups in term of gender, immigrant background and social, economic and cultural status. The lowest performers in both technical and professional schools are characterized by gender: males are more than females. On the other hand strong performers, especially in technical school, are more balanced between males and females. The ESCS average is below the OECD mean (equal to 0) and the Italian average (-0.123) in any group except among strong performers from technical schools. In technical schools, the mean of ESCS is above the Italian average (-0.591) among the lowest performers but below the national average $(0.281)$ among strong performers. While in professional schools, the social, economic and cultural conditions are the most critics in both the lowest and strong performers.

The analysis confirms also that, in school life, hardware as well as using desktop computer and printer is diffused in almost of the sampled students with a greater incidence in technical schools, especially among strong performers; on the other hand portable laptop is more used among the lowest performers, in particular from professional schools. That aspect can mean that personalized or individual activities are more diffused among students with low achievement, for which ICT is a support for student achievement. On the other hand, Internet connection is less available than hardware tools in all the examined groups, underlining a cultural problem of digital divide among Italian schools. Most of the students examined here spend no time using computer during classroom lessons, with a greater incidence in test language and science lessons and a lower incidence among students with modest performances in reading literacy.

The interesting aspects that emerged from the analysis are the different ways of using ICT, for example strong performers are more capable than lowest performers to do tasks on computer, except in creating databases, and the greater effect of having positive attitude 
PROBLEMS

OF EDUCATION

IN THE $21^{\text {st }}$ CENTURY

Volume 49, 2012

towards online reading and using computer on reading literacy among the lowest performers than among strong performers.

\section{Conclusions}

The focus on the technical and professional schools underlines that using ICT at school is greater among students with difficulties, the lowest performers, than among strong performers. Certainly motivation to do tasks by using computer and enjoyment in reading online can make the difference within the groups of the lowest performers: the more motivation and enjoyment towards ICT, the better performances in reading literacy. However, the program PISA is not able to say how much using ICT at school is effective on disadvantage students' achievement, because the relation between the ICT use at school and students' performances is negative or not statistically significant (OECD, 2010, 2011); moreover PISA doesn't deepen teachers' dimension and their pedagogical strategies to achieve disadvantage students. In conclusion, Italy shows its limits in using ICT not only at school but also in society. There is a gap in term of using ICT between low and high performers at different level of analysis, individual and collective, that underline the presence of a cultural digital divide gap in term of ICT usability that could be interesting to develop by new further designs of research able to deepen classrooms' dimension and their educational processes.

\section{References}

Accorsi, L., \& Gui, M. (2006). La socializzazione ai nuovi media. Riflessioni sul ruolo della scuola nelle rappresentazioni di studenti di istituti superiori. Scuola e città, 2.

Bentivegna, S. (2009). Disuguaglianze digitali. Le nuove forme di esclusione nella società dell'informazione. Bari: Laterza.

European Commission (2000). Communication from the Commission-e-Learning-Designing tomorrow's education. COM(2000) 318 final. Retrieved from http://ec.europa.eu/education/archive/elearning/ comen.pdf.

European Commission (2008). Communication from the Commission to the European Parliament, the Council, the European Economic and Social Committee and the Committee of the Regions - New Skills for New Jobs. Anticipating and matching labour market and skills needs, COM (2008) 868 final. Retrieved from http://eur-lex.europa.eu/LexUriServ/LexUriServ.do?uri=COM:2008:0868: FIN:EN:PDF.

Eurydice (2011). Key Data on Learning and Innovation through ICT at School in Europe 2011. Brussels: Education, Audiovisual and Culture Executive Agency. Retrieved from http://eacea.ec.europa.eu/ education/eurydice/documents/key_data_series/129en.pdf.

Gui, M., \& Accorsi, L. (2006). La socializzazione ai nuovi media. Riflessioni sul ruolo della scuola nelle rappresentazioni di studenti di istituti superiori. Scuola e città, 2.

Gui, M., \& Micheli, M. (2011). I giovani e la disuguaglianza digitale. Il dibattito e la situazione in Italia, Città in Controluce, 19-20, 48-74. Retrieved from http://boa.unimib.it/bitstream/10281/30598/3/ I_giovani_e_la_disuguaglianza_digitale.pdf.

Hargittai, E. (2002). Second-Level Digital Divide: Differences in People's Online Skills. First Monday, 7 (4). Retrieved from http://firstmonday.org/htbin/cgiwrap/bin/ojs/index.php/fm/article/ view/942/864.

Hargittai, E. (2010), Digital Na (t) ives? Variation in Internet Skills and Uses among Members of the "Net Generation”. Sociological Inquiry, 80 (1), 92-113. Retrieved from http://www.webuse.org/pdf/ Hargittai-DigitalNativesSI2010.pdf.

INVALSI (2011). Servizio Nazionale di Valutazione 2010-2011. La rilevazione degli apprendimenti A.S. 2010-2011. Frascati: INVALSI. Retrieved from http://www.invalsi.it/snv1011/.

INVALSI (2012). Rilevazioni Nazionali sugli Apprendimenti 2011-12. Frascati: INVALSI. Retrieved from http://www.invalsi.it/snv2012/index.php?action=home. 
ISTAT (2012a). La scuola e le attività educative. Anno 2011. Statistiche Report. Retrieved from http:// www.istat.it/it/archivio/71706.

ISTAT (2012b). Rapporto annuale 2011. Cittadini e nuove tecnologie. Anno 2011. Retrieved from http:// www.istat.it/it/archivio/48388.

Jenkins, H., Purushotma, R., Weigel, M., Clinton, K., \& Robinson, A. (2010). Culture partecipative e competenze digitali: media education per il XXI secolo. Milano: Guerini.

Melchiori, R. (2012), Le tecnologie nella didattica, Roma: Edizioni Nuova Cultura.

MIUR (2007). Persona, tecnologie e professionalità. Gli istituti tecnici e gli istituti professionali come scuole dell'innovazione. Studi e documenti degli annali della pubblica istruzione, 120-121. Retrieved from http://www.annaliistruzione.it/var/ezflow_site/storage/original/application/dee13 e637aa9e05b75172767928c545a.pdf.

OECD (2009a). PISA 2009 Assessment Framework. Paris: OECD. Retrieved from http://www.oecd.org/ pisa/pisaproducts/44455820.pdf.

OECD (2009b). PISA Data Analysis Manual. SPSS Second Edition. Paris: OECD. Retrieved from http:// browse.oecdbookshop.org/oecd/pdfs/free/9809031e.pdf.

OECD (2010). PISA 2009 Results: What students know and can do. Student performance in reading mathematics and science (Vol. 1). Paris: OECD. Retrieved from http://www.oecd.org/pisa/ pisaproducts/48852548.pdf.

OECD (2011). PISA 2009 Results: Student on Line. Digital Technologies and Performance. Paris: OECD. Retrieved from http://www.oecd.org/pisa/pisaproducts/pisa2009/48270093.pdf.

OECD (2012). PISA 2009 Technical Report. Paris: OECD. Retrieved from http://www.oecd-ilibrary.org/ education/pisa-2009-technical-report_9789264167872-en.

Pandolfini, V. (2010). The use of new technologies in teacher' professional development: new ways to enhance personal capabilities? IJSE - Italian Journal of Sociology of Education, 6 (3), 98-121.

Schizzerotto, A. (Ed.) (2002). Vite ineguali. Disuguaglianze e corsi di vita nell'Italia contemporanea. Bologna: Il Mulino.

Van Dijk, J. (2005). The deepening divide. Inequality in the Information Society. London: Sage. Available from http://www.utwente.nl/gw/mco/bestanden/digitaldivide.pdf.

\section{Endnotes}

1 Level of basic computer skills are measured by Eurostat in 2011 by a self-assessment approach about six computer-related items: copy or move a file or folder; use copy and paste tools to duplicate or move information within a document; use basis arithmetic formula (add, subtract, multiply, divide) in a spreadsheet; compress files; connect and install new devices, e.g. a printer or a modem; write a computer program using a specialized programming language. Individuals are grouped into: low level (those who carried out 1 or 2 of the 6 computer-related items); medium level ( 3 or 4 of the 6 computer-related items; high level (5 or 6 of the 6 computer-related items) (Eurostat, 4/10/2012).

2 Level of Internet skills are measured by Eurostat in 2011 by a self-assessment approach about six Internet-related items: use a search engine to find information; send an e-mail with attached files; post messages to chat-rooms, newsgroups or any online discussion forum; use the Internet to make telephone calls; use peer-to-peer file sharing for exchanging movies, music etc.; create a web page. Individuals are grouped into: low level (those who carried out 1 or 2 of the 6 Internet-related items); medium level ( 3 or 4 of the 6 Internet-related items); high level ( 5 or 6 of the 6 Internet-related items) (Eurostat, 4/10/2012).

3 Moreover detailed Italian surveys about digital skills and using ICT show other significant differences among the geographical areas of Italy (ISTAT, 2012a, 2012b).

4 For further information please see the website http://www.iea.nl/sites_2006.html.

5 PISA was implemented in 43 countries and economies in the first cycle (32 in 2000 and 11 in 2002), 41 in the second cycle (2003), 57 in the third cycle (2006), 75 in the fourth cycle (65 in 2009 and 10 in 2010) and 66 in the fifth cycle (2012). 
PROBLEMS

OF EDUCATION

IN THE $21^{\text {st }}$ CENTURY

Volume 49, 2012

6 In PISA 2000, when literacy was the major domain, the results are summarized on a single composite reading literacy scale having an average score of 500 points and a standard deviation of 100 across OECD countries.

7 For a summary description for the seven levels of proficiency in reading, please see OECD (2010:47).

8 The weighted sample is composed by 153,393 students from technical schools and 111,991 students from professional schools.

Advised by Dan Lacrama, Tibiscus University, Timisoara, Romania

Received: September 07, 2012

Accepted: November 26, 2012

Michela Freddano

$\mathrm{PhD}$ in Evaluation of Educational Processes and System, Researcher, University of Genova, Department of Educational Science, Corso A. Podestà

2, 16128, Genova, Italy.

E-mail: michela.freddano@unige.it

Website: http://valutazione.unige.it/index.php?option=com_content\&view=arti cle\&id $=92 \&$ ltemid $=30$

Paolo Diana

PhD., Researcher, University of Salerno, Via Ponte Don Melillo, 84084,

Fisciano, Salerno, Italy.

E-mail: diana@unisa.it

Website: http://www.unisa.it 